\title{
The effect of TQM on organisational performance: empirical evidence from the textile sector of a developing country using SEM
}

Shafiq, Muhammad

Lasrado, Flevy

Hafeez, Khalid

2017

This is the accepted manuscript of an article published by Taylor \& Francis in Total Quality Management \& Business Excellence on the 22 February 2017 available online:

https://dx.doi.org/10.1080/14783363.2017.1283211 


\title{
The impact of TQM on Organisational Performance: Empirical Evidence from Textile Sector of a Developing Country using SEM
}

\begin{abstract}
:
Total Quality Management (TQM) is a widely used management philosophy across many sectors. Organisations implement TQM in order to gain competitive advantage in terms of quality, productivity, customer satisfaction, and profitability. However, the literature seems inconclusive about the positive effect of TQM on organisational performance. Several studies argue that the effect of TQM practices on organisational performance need to be evaluated in different social, cultural, and economic settings. The effect of national culture on TQM implementation is also gaining importance. Therefore, this study provides empirical evidence from a developing country of South Asia. This study was conducted in the context of textile companies of Pakistan. The data was collected from the member companies of All Pakistan Textile Mills Association (APTMA) by using a questionnaire. The questionnaires were sent to 210 textile companies and the respondents were quality or production managers. Structural Equation Modelling (SEM) was used to investigate the relationship between TQM practices and organisational performance. The findings of this study indicate that TQM has a highly positive effect on organisational performance. These findings support the divergence argument which indicates that the positive effect of TQM on organisational performance is not limited only to the companies located in developed nations, but can also be equally achieved in the other parts of the world. All the TQM elements have positive relationship with financial and non-financial results. However, the element of people does not have significant relationship with financial and non-financial results.
\end{abstract}

Key words: TQM, Organisational Performance, Quality Management.

\section{Introduction}

In today's competitive environment, where customers are more conscious about product quality, the importance and adoption of quality improvement initiatives is are increasing day by day. A broad list of such initiatives has been found in literature including Advanced Manufacturing Technology (ATM), Total Quality Management (TQM), and Total Preventive Management (TPM), Just in Time (JIT), Six-Sigma and Lean Manufacturing. Selecting from 
among these emerging concepts, the focus of the current study is on TQM implementation and further investigation of its effects on organizational performance.

The concept of TQM flourished after the advent of quality movement led by Americans, such as Deming, Juran and Feigenbaum. In the 1950s, Deming taught statistical methods and Juran taught quality management techniques to the Japanese. Then the focus widened from quality of products to quality of all issues within an organization - the start of TQM. Japanese industry had embraced (TQM) in the 1950's and the resulting success led other countries to follow suit in the 1980's. Gradually TQM started to emerge as a new paradigm shift (Spencer, 1994) and a leading management idea tool (Yong and Wilkinson, 2001).

Organisations implement TQM in order to gain competitive advantage over others, to-win customers allegiance, gain business resources or obtain massive funding (Oakland, 2005; Douglas \& Judge 2001). Also, TQM exhibits high levels of benefits of improved customer focus, communication, team work and effectiveness; these benefits are due to joint problem solving, management commitment and employee empowerment (Witcher, 1994).

A considerable amount of the TQM literature has investigated whether there is an association between TQM practices and organisational performance. Empirical studies reveal contradictory findings. For example, substantial research provides empirical evidence that there is a positive association between TQM implementation and organisational performance (Bou-Llusar et al. 2009; Tari, Molina and Castejon 2007; Kaynak, 2003; Douglas and Judge, 2001; Easton and Jarrel, 1998). On the other hand, many studies indicate that there is a weak or no relationship between TQM practices and organisational performance, especially financial results (Corredor and Goni, 2010; Macinati, 2008; Benner and Veloso, 2008; Samson and Terziovski, 1999; Dow, Samson and Ford, 1999; Ho, Duffy and Shih 2001).

Several empirical studies argue that the social, cultural and economic conditions of a country might have the potential to affect TQM practices within a company (Kull and Wacker, 2010; Flynn and Saladin, 2006; Anwar and Jabnoun, 2006; Yoo, Rao and Hong, 2006; Prasad and Tata, 2003; Lagrosen, 2002; and Dahlgaard, Kristensen and Kanji, 1998). For example, Kull and Wacker (2010) found significant differences in the implementation of quality management practices among companies located in the East Asian cultures of China, Taiwan, and South Korea. Similarly, Flynn and Saladin (2006) identify that quality management practices were not equally effective in the USA, Japan, Germany, Italy and England. Therefore, Sila and 
Ebrahimpour (2005) suggest that relationship between TQM and organisational performance need to be explored in the context of a specific country. Forza and Filippini (1998) and Flynn and Saladin (2006) also suggest that the relationship between TQM and organisational performance needs to be examined in the context of other countries.

Therefore, this research will contribute by providing empirical evidence about the relationship between TQM practices and organisational performance from an under-researched developing country. Furthermore, the review of performance related TQM literature shows that there is a wide and varying range of criteria used in performance measurement frameworks. For example, many studies measure performance in terms of financial measures only, like market share value, return on investment and profit (e.g. Nicolau and Sellers, 2010; Corredor and Goni, 2010; Easton and Jarrel, 1998). These studies do not consider any non-financial outcomes such as customer satisfaction, process improvement, employee satisfaction or society results. Kaplan and Norton (1992) posit that traditional financial measures of accounting like returnon-investment and earning-per-share might give deceptive signals about organisational performance. However, studies such as Bou-Llusar et al. (2009), Martinez-Costa, Choi, and Martinez (2009) and Curkovic et al. (2000) consider this issue and take both the financial and non-financial measures of performance. Thus, in future studies this issue needs to be considered and researchers should use sufficiently wide constructs to measure organisational performance. This study uses both financial and non-financial measures to investigate the relationship between TQM practices and organisational performance.

\section{Literature Review}

\subsection{The Evolution of TQM}

In the 1980s, American companies were facing fierce competition in the global market from their Japanese counterparts. Japanese companies had made substantial improvements in formerly US-dominated industries, like automobiles, consumer electronics and machine tools. This reality was well-projected by NBC television in a program named "If Japan Can...Why Can't We" (Samson and Terziovski, 1999, p. 394). Marcus (2008, p.324) argues that in the 1970s and early 1980s the Americans began to respond to TQM;as it was seen as the reason for Japanese success. It was during this timeframe that TQM began to gain worldwide attention.

The literature seems unable to exactly identify the origin of TQM. Boje and Winsor (1993) argue that the Japanese pioneered TQM through the transfer of American management know- 
how. Yong and Wilkinson (2001) agree with Boje and Winsor (1993), believing that the formal beginnings of quality management can be traced back to Shewhart, who was a US statistician; his work was extended by other statisticians like Dodge, Romig, and Deming. Powell (1995) also linked TQM roots to the Union of Japanese Scientists and Engineers. Linstead et al. (2009, p.428) agree with Powell, describing that the attitudes and norms of Japanese workplaces can easily be identified in the teachings of the 'gurus' of quality management.

\subsection{Defining TQM}

In the last few decades, thousands of books and articles have been written about TQM, but a universal definition of what it is still cannot be found. Andersson, Eriksson and Torstensson (2006) consider that defining TQM is like the famous John Godfrey Saxe story "The Blind Men and the Elephant"; researchers and practitioners have adopted the definition which is most suited to their views (Boaden, 1997). Spencer describes a similar situation, "TQM is not a cutand-dried reality but an amorphous philosophy that is continuously enacted by managers, consultants, and researchers who make choices based not only on their understanding of principles of TQM but also on their own conceptual frameworks concerning the nature of organisations" (1994, p.448).

The literature seems to agree the scope of this management approach. Initially, both academics and practitioners considered it TQM to be an approach used for the improvement of product quality only, whereas now they consider that it could be used for the continuous improvement of every process within an organisation. Gryna et al. (2007, p.16) also support this view. This viewpoint is well explained by Evans \& Lindsay (2008, p.10). They argue that the concept of TQM has extended from the "quality of management" to the "management of quality". They considered that "rather than a narrow engineering or production-based technical discipline, quality took on a new role that permeated every aspect of running an organisation".

Fisher and Nair (2009, p.11) agree with Evans \& Lindsay (2008). They believe that "TQM in its broadest sense examines all aspects of management". Omachonu and Ross (2005, p.3) also give a similar explanation that "TQM is the integration of all functions and processes within an organisation in order to achieve continuous improvement of the quality of goods and services".

In a similar vein, Oakland (1993, p.22) defines TQM as "an approach to improve the competitiveness, effectiveness, flexibility of the whole organisation". Agreeing with the 
definitions of TQM given by the above-mentioned authors, Sadikoglu and Zehir (2010, p.13) assert that TQM is "a systematic quality improvement approach for firm-wide management for the purpose of improving performance in terms of quality, productivity, customer satisfaction, and profitability."

\subsection{TQM and Organisational Performance}

The question to now consider is whether TQM really helps the organisations in improving their performance in terms of quality, productivity, customer satisfaction, and profitability. In this section, we will examine the key literature which has investigated the relationship between TQM and organisational performance.

Leading quality researchers, like Deming, Crosby and Juran, support a positive association between quality implementation and organisational performance. For example, Deming (1986, p.1) asserts, "Productivity increases with improvement of quality. Low quality means high cost and loss of competitive position". Similarly, Crosby (1980, p.1) states, "if you concentrate on making quality certain, you can probably increase your profit by an amount equal to $5 \%$ to $10 \%$ of your sales". They also report many success stories of companies which implemented quality improvement initiatives. For example, Crosby (1984, p.148) describes a textile manufacturer saving $\$ 700,000$ from the cost of quality in the first six months. He also describes similar success stories from other manufacturing companies. He argues that these companies have saved millions of dollars by reducing error rates, minimising the cost of quality, eliminating customer complaints and decreasing material handling costs.

The results of considerable empirical studies conducted in various countries also support the positive associations between implementation of TQM and organisational performance. For instance, Hendricks and Singhal (1999) provide empirical evidence from six hundred quality award winning companies located in the USA that TQM implementation has a positive effect on organisational performance. They indicate that the award winning companies have a much better performance compared to non-award winning companies, in terms of operating income, total sales, total assets, return on sales and return on assets. Zairi, Letza and Oakland (1994) studied a five-year span of audited financial accounts of TQM and non-TQM UK companies. In this study, they examine 29 TQM companies. Twenty-two of these outperformed the industry averages in profit margin, return on total assets, turnover per employee, profit per employee, total assets per employee, fixed asset trends and average remuneration. Bou-Llusor et al. (2009) and Tari, Molina and Castejon (2007) provide empirical evidence from Spanish 
manufacturing and service organisations that TQM practices have a strong positive effect on organisational performance. Douglas and Judge (2001) provide empirical evidence from American hospitals that TQM practices are positively and significantly associated with financial performance. Prajogo and Sohal (2003) report that TQM practices are significantly and positively associated with product quality and innovation. They collected data from manufacturing and service organisations in Australia. Gryna et al. (2007, p.127) discuss the findings of a study based on the Profit Impact of Market Strategies (PIMS) database, which contains data from more than 450 manufacturing and service organisations. The findings of this study indicated that quality is the most important factor affecting organisational performance and underlines that companies with better quality have higher returns.

On the other hand, Harari (1993, p.33) maintains that by putting together the research conducted by independent companies such as Ernst and Young, McKinsey \& Co., Arthur D. Little and Rath \& Strong it is evident that "only about one-fifth, at best one-third, of TQM programmes in the United States and Europe have achieved significant or even tangible improvements in quality, productivity, competitiveness or financial returns". Other research also argues that the majority of TQM programmes were unable to achieve the expected performance goals (Rich, 2008; Miller, Hartwick and Breton-Miller 2004; Walsh, 1995). Macinati (2008) provides empirical evidence from Italian health care providers which indicate that quality management practices are not significantly related to financial results. Corredor and Goni (2010) offer empirical evidence from manufacturing and service organisations in Spain that only earlier adopters of TQM can get adequate benefits from the adoption of TQM. The findings of some of the major research which has investigated the relationship between TQM practices and business results are summarised in Table 1.

TQM implementation in well-publicized companies like Motorola, Millikan and Co, Xerox etc. doesn't mean that all firms after TQM implementation will be successful. -A myriad of issues like a lack of top management commitment, lack of customer, supplier and employee involvement during implementation or lack of financial resources may lead to failure. TQM implementation requires patience in order to get its true benefits (Handricks, and Sinhal, 2000).

The above-mentioned studies lead to the conclusion that the TQM relationship with different dimensions of organisational performance is inconclusive, thus further empirical research is needed to investigate this relationship in more depth. Sila and Ebrahimpour (2005, p.1144) suggested that: 
Certain factors may not be related to certain performance measures in a specific country or industry or type of firm simply because they are not applicable within that context and thus are not significant predictor of performance. Therefore, these issues must be explored in more detail in future studies since it is crucial that a company's resources and efforts be allocated to only those practices that will yield best performance for the organisation, if at all.

Similarly, Forza and Filippini (1998) suggest that the relationship between TQM and organisational performance needed to be examined in other environments as well. Sousa and Voss (2002, p.106) mention that there is a need for
More detailed and solid understanding of quality management's performance effects by using finer quality performance models (including all of the relevant variables and relationships) investigating the models' relationships across different contexts.

Furthermore, the review of the existing literature shows that the majority of studies which investigate the relationship between TQM and organisational performance are conducted in the context of the USA; and Japan, as well as the UK, Spain, Japan and other European countries. The studies indicated in Table 1 also highlight a similar trend. There is less research available which explores the association of TQM practices with different levels of organisational performance in South Asian countries like Bangladesh, Pakistan, India and Sri Lanka. Sila and Ebrahimpour (2005) suggest that several cross-country studies have been conducted, but it is an important area to be explored in more detail. Similarly, Forza and Filippini (1998) and Flynn and Saladin (2006) suggest that the relationship between TQM and organisational performance needs to be examined in the context of other countries. 
Table 1: The Relationship Between TQM Practices And Organisational Performance

\begin{tabular}{|c|c|c|c|c|}
\hline Study & Country & $\begin{array}{l}\text { Nature of } \\
\text { organisations }\end{array}$ & Research method & Findings \\
\hline $\operatorname{Tan}(2013)$ & Malaysia & $\begin{array}{l}\text { Managers of } \\
\text { family owned } \\
\text { business }\end{array}$ & Survey & Positive relation between TQM principals and OP \\
\hline Louise et al. (2013) & USA & $\begin{array}{l}\text { American } \\
\text { awarded } \\
\text { companies }\end{array}$ & $\begin{array}{l}\text { Observed the performance of } \\
\text { selected firms over } 11 \mathrm{yrs}\end{array}$ & $\begin{array}{l}\text { Positive relation between TQM implementation and } \\
\text { performance of firms }\end{array}$ \\
\hline $\begin{array}{l}\text { Corredor and Goni ( } \\
\text { 2010) }\end{array}$ & Spain & $\begin{array}{l}\text { Manufacturing } \\
\text { and services }\end{array}$ & $\begin{array}{l}\text { Analysis of secondary data } \\
\text { related to the firm's } \\
\text { profitability \& achievement of } \\
\text { quality awards. }\end{array}$ & $\begin{array}{l}\text { Earlier adopters of quality awards can get more } \\
\text { benefit as compare to late adopters. There was no } \\
\text { significant difference in the performance of TQM and } \\
\text { non-TQM firms. }\end{array}$ \\
\hline $\begin{array}{l}\text { Bou-Llusor et al. } \\
(2009)\end{array}$ & Spain & $\begin{array}{l}\text { Manufacturing } \\
\text { and services }\end{array}$ & $\begin{array}{lr}\text { Questionnaire } & \text { survey. } \\
\text { Respondents: CEOs \& quality } \\
\text { managers. } & \text { Analysis } \\
\text { Technique: SEM } & \\
\end{array}$ & $\begin{array}{l}\text { The excellence of enablers has a strong positive } \\
\text { effect on results excellence. Both MBNQA and } \\
\text { EFQM Excellence Model are the best models of } \\
\text { TQM. }\end{array}$ \\
\hline Macinati (2008) & Italy & $\begin{array}{l}\text { Health care } \\
\text { providers }\end{array}$ & $\begin{array}{lr}\text { Questionnaire } & \text { survey. } \\
\text { Respondents: } & \text { Managing } \\
\text { Director. Analysis } & \text { Technique: } \\
\text { Factor analysis, Correlations }\end{array}$ & $\begin{array}{l}\text { There is a no significant relationship between } \\
\text { financial results and quality management practices. } \\
\text { However, quality management practices are } \\
\text { positively associated with subjective performance. }\end{array}$ \\
\hline $\begin{array}{l}\text { Tari, Molina and } \\
\text { Castejon (2007) }\end{array}$ & Spain & $\begin{array}{l}\text { Manufacturing } \\
\text { and services }\end{array}$ & $\begin{array}{l}\text { Questionnaire } \quad \text { survey. } \\
\text { Respondents: } \quad \text { Managers, } \\
\text { Analysis Technique: SEM }\end{array}$ & $\begin{array}{l}\text { TQM practices have direct and indirect effect on } \\
\text { organisational performance. }\end{array}$ \\
\hline Feng et al. (2006) & $\begin{array}{l}\text { Australia } \\
\text { and } \\
\text { Singapor } \\
\text { e }\end{array}$ & & $\begin{array}{lr}\text { Questionnaire } & \text { survey, } \\
\text { Respondents: } & \text { Senior } \\
\text { Managers. } & \text { Analysis } \\
\text { Technique: SEM } & \\
\end{array}$ & $\begin{array}{l}\text { TQM dimensions like leadership \& people } \\
\text { management are more related to innovation, whereas } \\
\text { customer satisfaction \& process management are } \\
\text { more related to quality performance. }\end{array}$ \\
\hline $\begin{array}{l}\text { Sila and Ebrahimpur } \\
\text { (2005) }\end{array}$ & USA & Manufacturing & $\begin{array}{lr}\text { Questionnaire } & \text { survey. } \\
\text { Respondents: Senior /quality } \\
\text { managers. } & \text { Analysis } \\
\text { Technique: SEM } & \\
\end{array}$ & $\begin{array}{l}\text { Among different constructs of TQM, only leadership } \\
\text { and process management have a direct positive } \\
\text { relationship with business results. }\end{array}$ \\
\hline $\begin{array}{l}\text { Rahman and } \\
\text { Bullock (2005) }\end{array}$ & Australia & Manufacturing & $\begin{array}{l}\text { Questionnaire } \\
\text { Respondents: }\end{array}$ & $\begin{array}{l}\text { The hard and soft elements of TQM are positively } \\
\text { associated with each other. However, hard elements }\end{array}$ \\
\hline
\end{tabular}




\begin{tabular}{|c|c|c|c|c|}
\hline & & & $\begin{array}{l}\text { Analysis } \text { Technique: Factor } \\
\text { analysis, correlations \& } \\
\text { regression analysis }\end{array}$ & $\begin{array}{l}\text { have a direct effect on organisational performance, } \\
\text { whereas soft elements of TQM can affect } \\
\text { performance indirectly, through hard TQM elements. }\end{array}$ \\
\hline Kaynak (2003) & USA & $\begin{array}{l}\text { Manufacturing } \\
\text { and services }\end{array}$ & $\begin{array}{lr}\text { Questionnaire } & \text { survey. } \\
\text { Respondents: } & \text { Senior } \\
\text { managers. } & \text { Analysis } \\
\text { Technique: SEM } & \\
\end{array}$ & $\begin{array}{l}\text { TQM practices have a positive direct and indirect } \\
\text { effect on organisational performance. }\end{array}$ \\
\hline $\begin{array}{l}\text { Prajogo and Sohal } \\
\text { (2003) }\end{array}$ & Australia & $\begin{array}{l}\text { Manufacturing } \\
\text { and services }\end{array}$ & $\begin{array}{lr}\text { Questionnaire } & \text { survey. } \\
\text { Respondents: } & \text { Managers. } \\
\text { Analysis Technique: SEM }\end{array}$ & $\begin{array}{l}\text { TQM practices are positively and significantly related } \\
\text { to product quality and innovation. }\end{array}$ \\
\hline $\begin{array}{l}\text { Douglas and Judge } \\
\text { (2001) }\end{array}$ & USA & Hospitals & $\begin{array}{lr}\text { Questionnaire } & \text { survey and } \\
\text { secondary data, } & \text { Respondents: } \\
\text { CEO/Director } & \text { quality. } \\
\text { Analysis } & \text { Technique: } \\
\begin{array}{l}\text { Correlation \& } \\
\text { analysis }\end{array} & \text { Regression } \\
\end{array}$ & $\begin{array}{l}\text { TQM practices are positively and significantly } \\
\text { associated with financial performance and industry } \\
\text { expert rated performance. }\end{array}$ \\
\hline
\end{tabular}


Another gap in much of the current TQM literature on the relationship between TQM practices and organisational performance in manufacturing organisations is that such literature is dominated by industries like chemical, engineering, automotive, heavy machinery, electrical engineering and electronics. Only few studies are available in the context of the textile sector. The majority of textile companies are situated in countries like Pakistan, China, India and Egypt, all of which are developing countries. Interestingly, there is not a single comprehensive study available in the context of Pakistan, which attempts to identify an association between TQM practices and organisational performance. For this reason, there is an opportunity to contribute to the debate by carrying out a research project in this area.

\section{Textile Industry of Pakistan and Implementation of Quality Improvement Initiatives}

Textile is the largest manufacturing sector of Pakistan, contributing about $60 \%$ to total exports. It accounts for $46 \%$ of total manufacturing and employs $38 \%$ of the total workforce in the manufacturing sector. This sector is considered the backbone of the country's economy (Pakistan Economic Survey, 2010-11). According to Raza (2007), the fibre quality of Pakistani cotton is better than Chinese or Indian. It is also better in dye, shine, lustre and uniformity. $60 \%$ of Pakistani cotton can be categorised as medium-long staple, $37 \%$ medium staple, and $3 \%$ long staple. The bulk of world production presently ranges between medium-to-medium-long staple, so Pakistan can enter into this market with confidence. Pakistan was the third largest exporter of short staple textile products in the world. The third world is the biggest market for such types of product. This might be one of the potential areas for the Pakistani textile industry to grow in future.

On the other hand, globalisation is an inevitable phenomenon. It is no longer an option, but a fact whether one likes it or not. Countries like Pakistan have to manage their economies skilfully, to face the global crosscurrents. Due to the WTO regime, quota restrictions have been abolished and now trade is governed by GATT principles. Before the enforcement of the WTO regime, quotas for the developing countries restricted the textile trade. This was one of the reasons that countries like Pakistan were unable to access larger markets. However, the dismantling of the quota regime has initiated open and stiff competition in the international market (Raza, 2007).

According to the study conducted by Asian Development Bank Indian and Council for Research International Economic Relations (ICRIER) between late 2006 and early 2007. The findings of this study indicate that the Pakistani textile industry is facing serious challenges 
from textile products from China, Bangladesh and India. These countries are much more competitive in the quality and price than textile products from Pakistan. Indeed Pakistani textile companies have an advantage over their competitors in terms of price and scale. However, they are not competitive enough on product dimensions like product design, innovation, quality, and consistency and reliability (Asian Development Bank, 2009).

Similarly, according to Shafiq (2012), Pakistani textile industry has not prepared itself to face severe competition in the international market after dismantling of the quota. This might be the reason that these companies are unable to compete, even with the South Asian countries on the dimensions of performance like timely delivery, consistency and reliability, innovation and quality of their products. Therefore, without making fundamental changes in their management approach and emphasising on quality management these textile companies cannot get their decent share from the international market. Khan (2003) also mentions that considering the current competitive situation the development of the quality culture and a customer-centred approach is crucial for Pakistani businesses.

The review of the literature indicates that very little effort has been made to investigate the implementation of TQM in the textile sector of Pakistan. Only a few studies like Shafiq (2012), Hussain, Akhtar and Butt (2009), Masakure, Henson and Cranfield (2009) and Fatima and Ahmed (2006) are available. These studies give very limited information about the level of TQM adoption and their relationship with organisational performance. Indeed, Hussain, Akhtar and Butt (2009) provided some empirical evidence from the cotton yarn industry of Pakistan and highlighted that quality management practices adopted by cotton yarn mills were found positively correlated to each other. This research provides strong arguments to use the quality management practices collectively to realize the promised performance outcomes. However, Hussain, Akhtar and Butt (2009) are unable to provide a comprehensive model of the relationship between TQM practices and organisational performance.

Therefore, this study has attempted to bridge the gap in the existing TQM literature by providing empirical evidence about the relationship of TQM with organisational performance from an under- researched developing country's textile industries. This study will help practitioners and policy makers in extending their knowledge base of effective applications of TQM. Thus, the research question posed is: 
What is the relationship of TQM with organisational performance in the textile industry of Pakistan?

\subsection{Theoretical Model}

The proposed structural model is represented in Figure 1. In this model EFQM Excellence Model's enabler criteria is considered as the TQM framework as empirically validated by BouLlousar et al. (2009). Many other authors like Ghobadian and Woo (1996), Eskilden (1998), Vander Wiele et al. (2000) and Westlund (2001) have also argued that EFQM excellence framework could be considered as a TQM framework. Therefore, in this proposed structural model it is assumed that EFQM enabler's criteria constitute the TQM constructs.

\section{Figure 1: Theoretical Framework}

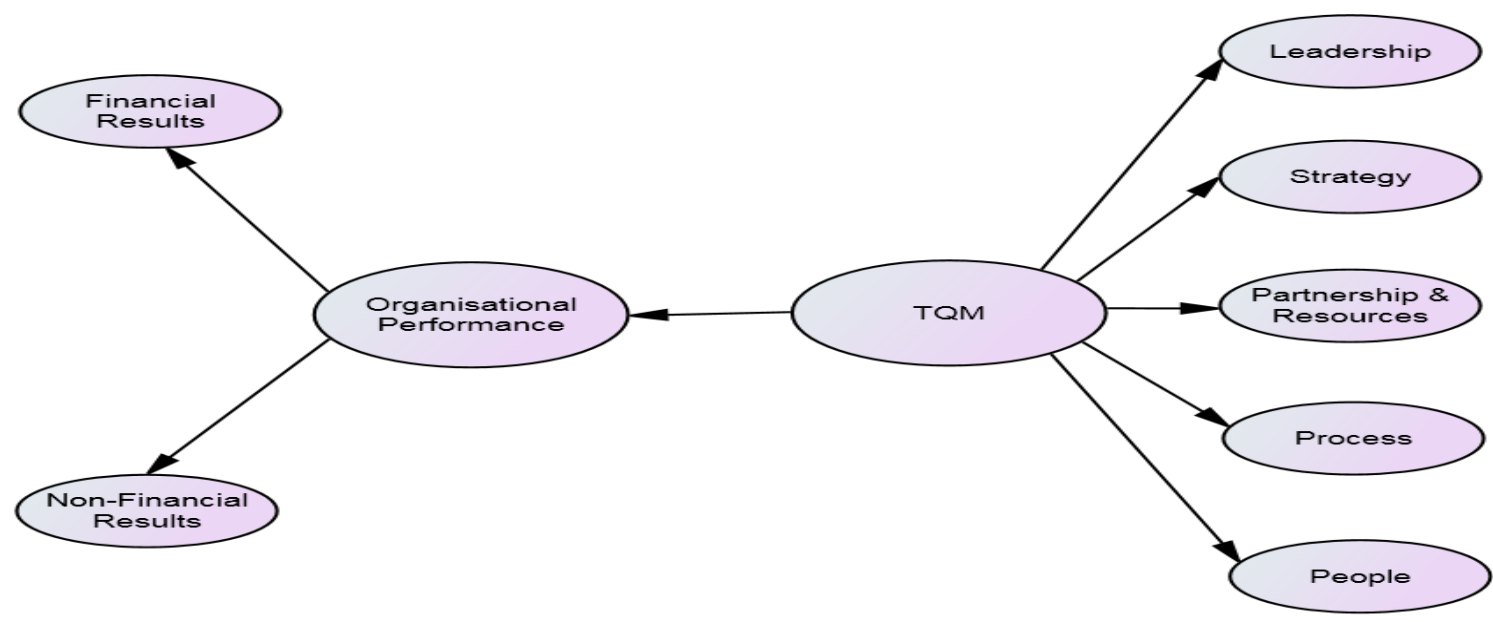

The review of the performance related TQM literature shows that there is a big difference in the use of performance measurement frameworks. The researchers do not use an adequate definition of organisational performance. For example, many studies measure performance in terms of financial measures only, like market share value, return on investment and profit (e.g. Nicolau and Sellers, 2010; Corredor and Goni, 2010; Easton and Jarrel, 1998). These studies do not consider any non-financial outcomes such as customer satisfaction, process improvement, employee satisfaction or society results adequately. Kaplan and Norton (1992) posit that traditional financial measures of accounting like return-on-investment and earnings- 
per-share might give deceptive signals about organisational performance. However, studies such as Bou-Llusar et al. (2009), Martinez-Costa, Choi, and Martinez (2009) and Curkovic et al. (2000) consider this issue and take both the financial and non-financial measures of performance. Thus, in this study the construct of organisational performance is comprised of both financial and non-financial measures.

\section{Methodology}

\subsection{Measurement Instrument}

The self-completion questionnaire was developed for this study after extensive literature review. There are many validated instruments are available in the literature (Saraph et al.1989; Flynn et al. 1994). However, majority of them are validated in different country and industry context.

For the development of existing instrument, initially the majority of items were taken from the existing instruments like Boulousar et al, 2009. The items which were not covered sufficiently were taken from EFQM Excellence Criteria (EFQM, 2010). Many other studies have also used the similar practice of following the excellence models criteria for the development of instruments. For example Boulousar et al, 2009 used EFQM to develop items and Black and Porter (1996) followed MBNQA criteria for the development of his instrument.

The measurement instrument was refined and tested by using a group of different experts from Pakistan, consisting of TQM practitioners, academic and managers. The final instrument has 30 items that measures TQM and 17 items which measure organizational performance.

For the measurement of TQM, 1-5 Likert scale was used. The respondents were required to respond the statements that most closely represent their observations about the way management practices are in their organization.

Similarly, the Likert Scale was used for the items that measured the organization's performance. Each respondent was required to respond to the statements based on their company's performance over the previous calendar year. For the Likert Scale, 1 was used for strongly disagree whereas 5 was used for strongly agree. 


\subsection{Population, Sample Size and Respondents}

This study was conducted in the context of textile companies of Pakistan. The member companies of All Pakistan Textile Mills Association (APTMA) were taken as population of this study. There are three hundred and seventy five textile mills are members of this association. These textile companies are located in all four provinces of Pakistan and belong to all categories (e.g. spinning, weaving, garments, composite etc.). All the initial details about the companies were taken from the APTMA members directory.

The members list of APTMA is taken as the sampling frame for this study. These textile companies are located in different geographical regions of the country. Berenson, Levine and Krehbiel (2009) suggest that under such conditions, when the population of a study is located across a wide geographical region, then cluster probability sampling is the best option to get a representative sample, because it is cost effective in comparison to simple random sampling.

Based on the explanation of the cluster probability sampling given by Berenson, Levine and Krehbiel (2009), the APTMA member textile companies were divided into four clusters. The division was done based on the four provinces of Pakistan. Among these provinces, Punjab is the largest province. Sixty-five percent of the total population of Pakistan live in this province and it is the largest producer of cotton. Fifty-six percent of APTMA member textile companies are located in the Punjab. The area and population of the Punjab is three times bigger than that of the UK. Thus, it was decided that all the member organisations of APTMA located in the province of Punjab would be considered as the sample for this study.

According to Saunders et al. (2009, p.219) if the population size is 400 , then the minimum sample size for confidence interval of $\pm 5 \%$ should be 196 . In the current study, the population size is 375 and the sample size is 210 , which is sufficient to achieve a confidence level of \pm $5 \%$.

The selection of respondents is a critical point in a questionnaire survey, which is based on many factors like the nature and level of the information required, and the language and terminologies used in the questionnaire. The majority of information required for this study can only be taken from employees working at the managerial level. Therefore, it was decided that the managers would be the respondents in this study. Many studies are based on a single respondent from each company. For example, the studies conducted by Hussain, Akhtar and Butt (2009) and Bou-Llusor et al. (2009) are based on a single response, and the respondents 
were the quality or production managers. Similarly, this study is based upon a single response from each company and respondents were quality or production managers.

\subsection{Scale Reliability and Validity:}

The items which constitute TQM and organizational performance were screened first by using Confirmatory Factor Analysis (CFA). This was done to establish whether the items really measured their assigned practices. The unidimensionality reliability, convergent validity and criteria related validity were also assessed.

\subsubsection{Unidimensionality Analysis:}

CFA was used to evaluate the unidimensionality of TQM and organizational performance constructs. Bentler and Bonnet (1980) suggested a cut-off value of comparative Fit Index 0.90. However, Hu and Bentler (1999) argued that this value should be close to 0.95 for a better fit and value of Standardized Root Mean Square Residual (SRMR) should be less than 0.08. The Table 3 indicates that values of CFI ranges from 0.945 to 0.98 and the values of SRMR ranges from 0.054 to 0.032 . The values mentioned above indicate that constructs are unidimensional.

\subsubsection{Reliability Analysis:}

The reliability of the constructs are widely evaluated by using the value of Cronbach's Alpha. The Cronbach's Alpha value more than 0.70 indicates the better reliability of the construct (Bryman, 2008). From Table 2, the alpha value for four TQM constructs and two organizational performance ranges from $0.738-0.868$. The overall value of Cronbach's alpha for TQM construct is 0.859 whereas the value of alpha for organizational performance is 0.805 . These values indicate that all constructs are highly reliable.

\subsubsection{Convergent Validity:}

Bagozzi et al (1991) suggested that CFA could be used to evaluate that convergent validity. The values of factor loading could be used to establish the convergent validity. The convergent validity could be established if all factors loading have the significant values on their respective constructs. From Table 2, all the factors loadings range from 0.413 and 0.9 and are significant on their respective constructs.

\subsubsection{Criterion - Related Validity Analysis}

According to Nunnally (1978), the criterion-related validity indicates the level to which items in a construct correlate with external criterion. In this study the construct of TQM is the independent variable or predictor whereas the construct of organizational performance is the 
dependent variable. The Table 4 indicates that the construct of TQM and its constituting subconstructs have the significant and positive bivariate correlations with the construct of organizational performance. The values of coefficient correlation varies from 0.184 to 0.582 these relationships are statistically significant at $\mathrm{P}<0.001$ except people construct which has $\mathrm{P}<0.06$. All of these values indicate that criterion-related validity exists. 


\begin{tabular}{|c|c|c|c|c|c|c|c|c|c|c|}
\hline & $\mathrm{X} 2$ & d.f & $\mathrm{X} 2 / \mathrm{d} . \mathrm{f}$ & p-Value & CFI & SRMR & $\begin{array}{l}\text { Factor } \\
\text { Loadings }\end{array}$ & $\begin{array}{l}\text { Cronbach's } \\
\text { Alpha }\end{array}$ & Mean & $\begin{array}{l}\text { Standard } \\
\text { Deviation }\end{array}$ \\
\hline TQM & 81.29 & 50 & 1.6 & 0.003 & $\begin{array}{l}0.94 \\
5 \\
\end{array}$ & 0.054 & & 0.859 & 3.94 & .569 \\
\hline Leadership & & & & & & & .99 & 0.738 & 4.11 & .667 \\
\hline People & & & & & & & .413 & 0.868 & 3.69 & .913 \\
\hline $\begin{array}{l}\text { Partnership } \\
\text { \& Resources }\end{array}$ & & & & & & & .480 & 0.746 & 3.83 & .909 \\
\hline Process & & & & & & & .887 & 0.854 & 4.12 & .632 \\
\hline $\begin{array}{l}\text { Business } \\
\text { Results }\end{array}$ & 17.03 & 13 & 1.3 & 0.19 & 0.98 & 0.032 & & 0.805 & 3.90 & .563 \\
\hline $\begin{array}{l}\text { Non-Financial } \\
\text { Results }\end{array}$ & & & & & & & .481 & 0.848 & 3.85 & .729 \\
\hline $\begin{array}{l}\text { Financial } \\
\text { Results }\end{array}$ & & & & & & & .786 & 0.738 & 3.94 & .696 \\
\hline
\end{tabular}




\begin{tabular}{|c|c|c|c|c|}
\hline & $\begin{array}{l}\text { Measurement } \\
\text { model for TQM }\end{array}$ & $\begin{array}{l}\text { Measurement model for } \\
\text { Organisational Performance }\end{array}$ & $\begin{array}{l}\text { Structural } \\
\text { model }\end{array}$ & $\begin{array}{l}\text { Recommended values for satisfactory } \\
\text { fit of a model to data }\end{array}$ \\
\hline$\chi^{2 / \mathrm{df}}$ & $81.293 / 50=1.6$ & $17.037 / 13=1.3$ & $\begin{array}{l}232.865 / 1 \\
45=1.6\end{array}$ & $<3.0$ \\
\hline $\begin{array}{l}\text { Root Mean Square Error of } \\
\text { Approximation (RMSEA) }\end{array}$ & 0.079 & 0.055 & .07 & $<0.08$ \\
\hline Comparative Fit Index (CFI) & 0.945 & 0.98 & 0.91 & $>0.90$ \\
\hline $\begin{array}{l}\text { Akaike's Information Criterion } \\
\text { (CAIC) }\end{array}$ & 238.792 & 101.411 & 485.989 & \\
\hline $\begin{array}{r}\text { Parsimony Goodness-of-Fit } \\
\text { Index (PGFI) }\end{array}$ & 0.569 & 0.443 & 0.614 & $>0.50$ \\
\hline $\begin{array}{r}\text { Parsimony Normed Fit Index } \\
\text { (PNFI) }\end{array}$ & 0.660 & 0.584 & 0.67 & $>0.50$ \\
\hline goodness of fit index (GFI) & 0.888 & 0.95 & 0.804 & Close to 1 \\
\hline
\end{tabular}




\begin{tabular}{|c|c|c|c|c|c|c|c|c|c|}
\hline \multicolumn{10}{|c|}{ Table 4: Correlations between the constructs of TQM and Business Results } \\
\hline & & $\begin{array}{c}\text { Financial } \\
\text { Result }\end{array}$ & Leadership & People & $\begin{array}{l}\text { Partnership } \\
\text { \& Resources }\end{array}$ & Process & TQM & \begin{tabular}{|c|} 
Non-Financial \\
Results
\end{tabular} & $\begin{array}{c}\text { Business } \\
\text { Results }\end{array}$ \\
\hline FR & Pearson Correlation & 1 & & & & & & & \\
\hline \multirow{2}{*}{ Lead } & Pearson Correlation & $.400^{* *}$ & 1 & & & & & & \\
\hline & Sig. (2-tailed) & .000 & & & & & & & \\
\hline \multirow{2}{*}{ People } & Pearson Correlation & .140 & $.401^{* *}$ & 1 & & & & & \\
\hline & Sig. (2-tailed) & .160 & .000 & & & & & & \\
\hline \multirow{2}{*}{$\begin{array}{l}\text { Part \& } \\
\text { Res. }\end{array}$} & Pearson Correlation & $.303^{* *}$ & $.330^{* *}$ & $.268^{* *}$ & 1 & & & & \\
\hline & Sig. (2-tailed) & .002 & .001 & .006 & & & & & \\
\hline \multirow{2}{*}{ Process } & Pearson Correlation & $.428^{* *}$ & $.713^{* *}$ & $.244^{*}$ & $.399^{* *}$ & 1 & & & \\
\hline & Sig. (2-tailed) & .000 & .000 & .013 & .000 & & & & \\
\hline \multirow{2}{*}{ TQM } & Pearson Correlation & $.413^{* *}$ & $.784^{* *}$ & $.694^{* *}$ & $.715^{* *}$ & $.744^{* *}$ & 1 & & \\
\hline & Sig. (2-tailed) & .000 & .000 & .000 & .000 & .000 & & & \\
\hline \multirow{2}{*}{ NFR } & Pearson Correlation & $.248^{*}$ & $.324^{* *}$ & .150 & $.578^{* *}$ & $.427^{* *}$ & $.505^{* *}$ & 1 & \\
\hline & Sig. (2-tailed) & .012 & .001 & .133 & .000 & .000 & .000 & & \\
\hline \multirow{2}{*}{$\begin{array}{l}\text { Business } \\
\text { Results }\end{array}$} & Pearson Correlation & $.779^{* *}$ & $.457^{* *}$ & .184 & $.562^{* *}$ & $.541^{* *}$ & $.582^{* *}$ & $.801^{* *}$ & 1 \\
\hline & Sig. (2-tailed) & .000 & .000 & .065 & .000 & .000 & .000 & .000 & \\
\hline
\end{tabular}




\section{Results of Structural Model}

The proposed structural model is presented in Figure 1. The goodness of fit statistics used for the assessment of fit of data for the proposed model is given in Table 3. From Table 3, the values of $\mathrm{RMSEA}=0.07, \mathrm{CFI}=0.91, \mathrm{x}^{2} / \mathrm{df}=1.6, \mathrm{PGFI}=0.614$ and $\mathrm{PNFI}=0.67$. All of these values are less or close to recommended values for satisfactory fit of a model. Therefore, these values indicate that the structural model has the best fit. Furthermore, the value of regression weight of TQM on organizational performance is 0.72 at $\mathrm{P}<0.000$. This indicates that $72 \%$ change in the business results could be explained on the basis of TQM.

Table 4 indicates that the TQM constructs of leadership, process and Partnership \& Resources have the significant positive correlation with the financial and non-financial results. Among these constructs Partnership \& Resources $(\mathrm{r}=0.578, \mathrm{p}<0.000)$ has the highest positive correlation with non-financial results followed by the construct of Process ( $r=0.428, p<0.000)$. Leadership $(\mathrm{r}=0.324, \mathrm{p}<0.001)$ has the lowest positive correlation with non- financial results. On the other hand, the construct of process $(r=0.427, \mathrm{p}<0.000)$ has the highest positive correlation with financial results followed by leadership $(\mathrm{r}=0.400, \mathrm{p}<0.001)$ and partnership \& resources $(r=0.303, p<0.002)$. However, the construct of people does not have any significant relationship with financial and non-financial results. 


\section{Discussion on Results and Findings}

The results of the structural model indicate that the data had a good fit to the proposed model. Therefore, this study provided the support for the positive and significant effect of TQM on the organisational performance.

This study supported the teachings of the gurus of quality like Deming, (2000, 1986), Crosby (1984) and Juran and Godfrey (1999). Many earlier studies support the findings of this study. For example, the current study supports the findings of Bou-Llusar et al. (2009) that the overall construct of TQM has a significant positive association with the business results. Indeed, there were some contextual and analytical differences existing in both studies. For example, BouLlusar et al. (2009) conducted their study in the context of both the manufacturing and service organisations of Spain which is quite different from the context of the current study. They also used different statistical analyses for the data compared to the current study, such as the structural equation modelling. However, both studies used the same EFQM excellence model as the TQM framework for the investigation of the relationship between TQM and business results.

Similarly, this study agrees with Kaynak (2003), although the two studies were conducted in different countries and industrial contexts. In her study Kaynak (2003) provides empirical evidence from firms located in the 48 contiguous states of the USA. The current study supports her results. She also used a questionnaire survey for the collection of data. The design of the questionnaire in these two studies was a little different. For example, she identified the TQM constructs from the literature instead of using the EFQM Excellence framework, whereas the questionnaire design for the current study was based on the EFQM excellence model's criteria.

This study also supports the findings of Tari, Molina and Castejon (2007), Samson and Terziovski (1999), and Choi and Eboch (1998). In addition, this research also confirms the results in of Easton and Jarrel (1998) that TQM practices have a positive effect on business results. In contrast to the current study they collected performance related data from publically available financial reports and using structured interviews with 108 firms who had seriously attempted to implement TQM systems. Similarly, this study supports the arguments of Hendricks and Singhal (1996) that quality-award- winning organisations perform better compared to non-TQM firms. Both studies basically indicate that TQM practices have a positive association with the achievement of business results. 
The findings of this study also indicate an interesting pattern of relationships between TQM constructs and financial \& non-financial results. Comparatively, hard TQM elements like process and partnership \& resources have highest positive relationships with non-financial results whereas the soft TQM elements like people does not have any significant relationship with non-financial and financial results. The non-significant relationship of people construct may be explained in the light of findings of Shamsur-Rehman (2005). He provided the empirical evidence that certain hard TQM elements affect the organisational performance however, it is important that these hard elements are supported by soft elements. In this study only direct relationship of TQM constructs is identified. However, based upon the findings of Shamsur-Rehman (2005) it may be inferred that the element of people may has the indirect relationship with financial and non-financial results.

The above discussion shows that the findings of this study support the results of many previous studies. However the result of some work (Mancinati, 2008, Su et al. 2008) is different from the results obtained here. For example, Mancinati (2008) highlights that there is a lack of significant statistical relationship between financial performance and quality management implementation. A close look at both studies indicates that Mancinati (2008) conducted his study in the health care providers of Italy which have an entirely different context in comparison with the sample in the current study. Health care providers could be categorised as the service sector, which provide services to the local community, whereas the textile companies of Pakistan have entirely different processes. These companies produce products to export all over the world. Thus, there is no comparison between the samples of these two studies.

This study also contributes in the important debate in operations management literature related with convergence vs divergence argument. Convergence hypothesis asserts that learning will lead managers from different cultures to adopt the same management practices and organizations in different countries can mitigate the effect of national culture and adopt universal practices. On the other hand, Divergence hypothesis questions the universal applicability of any standardized business practice. It argues that business practice should be adapted to national context and work practices of different organizations vary in different countries (Naor et al., 2010; Vecchi and Brennan, 2011; 2009). The empirical evidence in this study is provided from an under researched developing country and the findings of this study supports the convergence hypothesis. Thus, it could be concluded that TQM practices have the similar effect on organisational performance as they have in other national cultures. Therefore, 
Pakistani textile industry should have the confidence on the TQM practices and can reap the benefits of implementing such practices in the Pakistani textile industry.

\section{Conclusion:}

The findings of this study indicated that TQM has a strong positive effect on organisational performance. These findings support the argument of TQM proponents that companies can achieve the higher levels of both financial and non-financial results by implementing TQM philosophy. Thus this study supports the divergence argument by providing empirical evidence from the textile sector of a developing country. This study indicated that the positive effect of TQM on organisational performance are not limited only to companies located in developed nations, but can also be equally achieved in the other parts of the world. Furthermore, this study shows that the textile industry can achieve similar benefits from TQM implementation as those obtained by other types of manufacturing companies. Pakistani textile sector has to focus on the implementation of TQM practices if they really want to improve the quality of their products and to be competitive in the international market.

This study also provided the empirical evidence that majority of the TQM constructs has positive and significant relationship with financial and non-financial results. Among these elements hard TQM elements like process and partnership \& resources have highest positive relationships with non-financial results whereas the soft TQM element like people does not have any significant relationship with non-financial and financial results. It does not mean that soft TQM elements like people do not have any association with business results. Such type of elements may affect business results through other hard TQM elements. Therefore, in future studies indirect relationship of soft TQM elements may need to be explored in further details in the context of textile industries.

Furthermore, to understand the effect of TQM on organisational performance, longitudinal studies are required in comparison to cross-sectional research design. Along with perceptual data, other types of data such as annual financial reports will give further insights of the relationship between TQM elements and financial results. 


\section{References}

Ahire, S.L. and Dreyfus, P. (2000). The impact of design management and process management on quality: an empirical investigation. Journal of Operations Management, 18, $549-575$.

Anwar, A.S. and Jabnoun, N. (2006). The development of a contingency model relating national culture to Total Quality Management.International Journal of Management, 23(2), 272-280.

Andersson, R., Eriksson, H. and Torstensson, H.K. (2006). Similarities and differences between TQM, six sigma and lean. The TQM Magazine, 18(3), 282-296.

Argyrous, G. (2008). Statistics for Research with a guide to SPSS Second Edition. Los Angeles: Sage Publications.

Asian Development Bank. Study on intraregional trade and investment in South Asia. Mandaluyong, Philippines. (2009). Available at http://www.adb.org/Documents/Books/Intraregional-Trade-Investment/default.asp [Accessed 15 February 2011].

Bagozzi, Richard P., Yi, Youjae,. Phillips, Lynn W. (1991). Assessing construct validity in organizational research. Administrative Science Quarterly. 36 , 421 - 58.

Benner, M.J. and Veloso, F.M. (2008). ISO 9000 practices and financial performance: a technology coherence perspective. Journal of Operations Management, 26, 611-629.

Bentler, P. M., \& Bonett, D. G. (1980). Significance test and goodness of fit in the analysis of covariance structures. Psychological Bulletin, 88, 588-606

Briggs, S. R. and Cheek, J. M. 1986.The role of factor analysis in the development and evaluation of personality scales. Journal of Personality, 54, 106-148. 
Berenson, M.L., Levine, D.M. and Krehbiel, T.C. (2009). Basic business statistics. Eleventh Edition. New Jersey: Pearson Education, Inc.

Black, S.A. and Porter, L.J. (1996).Identification of the critical factors of TQM. Decision Sciences, 27(1). 1-21.

Boaden, R.J. (1997). What is total quality management... and does it matter? Total Quality Management, 8(4), 153-171.

Boje, D.M. and Winsor, R.D. (1993). The resurrection of Taylorism: Total Quality Management's hidden agenda. Journal of Operational Change Management, 6(4), 57-70.

Bou-Llusar, J.C., Ana B, E.T., Vicete, R.P. and Beltrain-Martin, I. (2009). An empirical assessment of the EFQM excellence model: Evaluation as a TQM framework relative to the MBNQA Model. Journal of Operations Management, 27, 1-22.

Boulter. A., Bendell, T. and Dahlgaard, J. (2013). Total quality beyond North America: A comparative analysis of the performance of European Excellence Award winners. International Journal of Operations \& Production Management, Vol. 33 Iss: 2, pp.197 - 215

Bryman, A. (2008). Social Research Methods. Third Edition. New York: Oxford University Press Inc.

Calvo-Mora, A., Leal, A. and Roldan., J.L. (2005). Relationships between the EFQM model criteria: a study in Spanish universities. Total Quality Management, 16(6), 741-770.

Choi, T.Y. and Eboch, K. (1998). The TQM paradox: Relations among TQM practices, plant performance, and customer satisfaction. Journal of Operations Management, 17, 59-75.

Corredor, P. and Goni, S. (2010). TQM and performance: Is the relationship so obvious? Journal of Business Research, 22(5), 529-538. 
Crosby, P. B. (1980). Quality is free: The art of making quality certain, New York, McGrawHill, Inc..

Crosby, P.B. (1984). Quality without tears. New York: McGraw- Hill, Inc..

Curkovic, S., Melnyk, S., Calantone, R. and Handfeld, R. (2000). Validating the Malcolm Baldrige National Quality Award Framework through structural equation modelling. International Journal Production Research, 38(4), 765-791.

Dahlgaard, J.J., Kristensen, K. and Kanji, G.K. (1998). Quality management practices: a comparative study between East and West. International Journal of Quality and Reliability Management, 15(8/9), 812-826.

Demirbag, M., Tatoglu, E., Tekinkus, M. and Zaim, S. (2006). An analysis of the relationship between TQM implementation and organisational performance: Evidence from Turkish SMEs. Journal of Manufacturing Technology Management, 17(6), 829-847.

Deming, W.E. (1986). Out of the crisis: Quality, productivity and competitive position. $19^{\text {th }}$ Edition. Melbourne: Cambridge University Press.

Dijkstra, L. (1997). An empirical interpretation of the EFQM framework.European Journal of Work and Organisational Psychology, 6(3), 321-341.

Douglas, T.J. and Judge, W.Q. (2001). Total quality management implementation and competitive advantage: The role of structural control and exploration. Academy of Management Journal, 44(1), 158-169.

Dow, D., Samson, D. and Ford, S. (1999). Exploding the myth: do all quality management practices contribute to superior quality performance? Production and Operation Management, $8,1-27$.

Easton, G.S. and Jarrel, S.L. (1998). The effect of Total Quality Management on corporate performance: An empirical investigation. Journal of Business, 71(2), 253-307. 
Eskildsen, J.K., and Dahlgaard., J. J. (2000). A causal model for employee satisfaction. Total Quality Management, 11(8), 1081-1094.

Eskildsen, J.K., Kristensen, K. and Juhl, H.J. (2001). The criterion weights of the EFQM excellence model.International Journal of Quality \& Reliability Management, 18(8), 783-795.

European Foundation for Quality Management. (2003). EFQM Excellence Model.

Evans, J.R. and Lindsay, W.M. (2008). Managing for quality and performance excellence. Seventh Edition. Mason: Thomson Corporation.

Fatima, M. and Ahmed, E. (2006). Quality Management in Pakistan's Bedwear Industry. Quality Engineering, 18, 443-451.

Feng, J., Prajogo, D.I., Tan, K.C. and Sohal, A.S. (2006). The impact of TQM practices on performance: A comparative study between Australian and Singaporean Organisations. European Journal of Innovation Management, 9(3), 269-278.

Fisher, N.I. and Nair, V.N. (2009). Quality management and quality practice: Perspectives on their history and their future. Applied Stochastic Models In Business And Industry, 25, 1-28.

Field, A. (2005). Discovering statistics using SPSS. Second Edition. London, Thousand Oaks, New Delhi: SAGE Publications.

Flynn, B.B., Saladin, B. (2006). Relevance of Baldrige constructs in an international context: A study of national culture. Journal of Operations Management, 24(5), 583-603.

Flynn, B.B., Schroeder, R.G. and Sakakibara, S. (1994). A framework for quality management research and an associated measurement instrument.Journal of Operations Management, 11, 339-366.

Forza, C. and Flippini, R. (1998). TQM impact on quality performance and customer satisfaction: a casual model. International Journal of Production Economics, 55, 1-20. 
Ghobadian, A. and Woo, H.S. (1996). Characteristics, benefits and shortcomings of four major quality awards.International Journal of Quality and Reliability Management, 13(2), 10-44.

Gryna, F.M., Chua, R.C.H. and DeFeo, J.A. (2007). Juran's quality planning and analysis. New York: The McGraw-Hill.

Harari, O. (1993). Ten reasons why TQM doesn't work.Management Review, (January), 3338.

Haynes et al. (1995). Content validity in psychological assessment: A functional approach to concepts and methods. Psychological Assessment, 7, 238-247.

Hendricks, K.B. and Singhal, V.R. (2001). Firm characteristics, total quality management, and financial performance. Journal of Operations Management, 19, 269-285.

Hendricks, K.B. and Singhal, V. (1996). Quality awards and market value of the firm: an empirical investigation. Management Science, 42(3), 415-436.

Hendricks, K.B. and Singhal, V.R. (1999). Don’t count TQM out. Quality Progress, April, 3542.

Ho, C.C.K., Duffy, V.G. and Shih, H.M. (2001). Total quality management: an empirical test for mediation effect. International Journal of Production Research, 39(3), 529-548.

Ho, C.C.K., Duffy, V.G. and Shih, H.M. (2001). Total quality management: an empirical test for mediation effect. International Journal of Production Research, 39(3), 529-548.

Hussain, T., Akhtar, N.A. and Butt, N.S. (2009). Quality management: A case from Pakistan cotton yarn industry. Journal of Quality and Technology Management, 5(1), 1-23.

Juran, J.M., Godfrey, A.B. (1999). Juran's Quality Handbook. Fifth Edition. New York: McGraw-Hill Companies Inc. 
Kaplan, R.S. and Norton, D.P. (1992). The balanced scorecard measures that drive performance. Harvard Business Review, (January-February), 71-79.

Kaynak. (2003). The relationship between total quality management practices and their effects on firm performance.Journal of Operations Management, 21(4), 405-435.

Khan, J.H. (2003). Impact of Total Quality Management on productivity. The TQM Magazine, 15(6), 374-380.

Kinnear, P.R. and Gray, C.D. (2010). PASW statistics 17 made simple. New York: Taylor \& Francis Group.

Kull, T.J. and Wacker, J.G. (2010). Quality management effectiveness in Asia: The influence of culture. Journal of Operations Management, 28, 223-239.

Lagrosen, S. (2002). Quality management in Europe: a cultural perspective. The TQM Magazine, 14(5). 275-283.

Linstead, S., Fulop, L. and Lilley, S. (2009). Management \& organisation: A critical text, 2nd Edition: Palgrave Macmillan.

Macinati, M.S. (2008). The relationship between quality management systems and organisational performance in the Italian National Health Services. Health Policy, 85:228-241.

Martinez-Costa, M., Choi, T.Y. and Martinez, J.A. (2009). ISO 9000/1994, ISO 9001/2000 and TQM: The performance debate revisited. Journal of Operations Management, 27, 495-511.

Marcus, A.I. (2008). Would you like fries with that, Sir?' The evolution of management theories and the rise and fall of total quality management within the American federal government.Management \& Organisational History, 3(3-4), 311-338.

Masakure, O., Henson, S. and Cranfield, J. (2009). Standards and export performance in developing countries: Evidence from Pakistan. The Journal of International Trade \& Economic Development, 18(3), 395-419. 
Miller, D., Hartwick, J. and Breton-Miller, I.L. (2004). How to detect a management fad and distinguish it from a classic.Business Horizons, 47(4), 7-16.

Naor, M., Linderman, K., \& Schroeder, R. (2010). The globalization of operations in Eastern and Western countries: unpacking the relationship between national and organizational culture and its impact on manufacturing performance. Journal of Operations Management, 28(3), 194-205.

Neuman, W.L. (2006). Social research methods: Qualitative and Quantitative Approaches. Sixth Edition: Pearson International Edition.

Nicolau, J.L. and Sellers, R. (2010). The quality of quality awards: Diminishing information asymmetries in a hotel chain. Journal of Business Research, 63, 832-839.

Nunnally, J.C., (1978). Psychometric Theory. McGraw-Hill, New York.

Oakland, J. S. (2004). Oakland on quality management, Oxford, Elsevier ButterworthHeinemann Publications.

Omachonu, V.K. and Ross, J.E. (2005). Principles of total quality.Taylor \& Francis e-Library. Pallant, J. (2010). SPSS survival manual: A step-by-step guide to data analysis using SPSS. 4th Edition. Berkshire: Open University Press, McGraw-Hill.

Powell, T.C. (1995). Total quality management as competitive advantage: A review and empirical study. Strategic Management Journal, 16, 15-37.

Prasad, S. and Tata, J. (2003). The role of socio-cultural, political-legal, economic, and educational dimensions in quality management.International Journal of Operations and Production Management, 23(5), 487-521.

Prajogo, D.I. and Sohal, A.S. (2003). The relationship between TQM practices, quality performance, and innovation performance: An empirical examination. International Journal of Quality and Reliability Management, 20(8), 901-918. 
Rahman, S. and Bullock, P. (2005). Soft TQM, hard TQM, and organisational performance relationship: an empirical investigation. The International Journal of Management Sciences, $33,73-83$.

Rao, S.S., Raghunathan, T.S. and Solis, L.E. (1999). The best commonly followed practices in the human resource dimension of quality management in new industrializing countries: The case of China, India and Mexico. International Journal of Quality \& Reliability Management, $16(3), 215-226$.

Raza, A. (2007). Growth of textile industry in Pakistan vis-a-vis value addition. PhD, Hamdard University.

Rich, E. (2008). Management fads and information delays: An exploratory simulation study. Journal of Business Research, 61, 1143-1151.

Sadikoglu, E. and Zehir, C. (2010). Investigating the effects of innovation and employee performance on the relationship between total quality management practices and firm performance: An empirical study of Turkish firms. International Journal of Production Economics, 127, 13-26.

Samson, D. and Terziovski, M. (1999). The relationship between total quality management practices and operational performance. Journal of Operations Management, 17(4), 393-409.

Rahman, S.U. and Bullock, P., 2005. Soft TQM, hard TQM, and organisational performance relationships: an empirical investigation. Omega,33(1), pp.73-83.

Saraph, J.V., Benson, G.P. and Schroeder, R.G. (1989). An instrument for measuring the critical factors of Quality Management. Decision Sciences, 20, 810-829.

Saunders, M., Lewis, P. and Thornhill, A. (2009).Research methods for business students. 5th Edition. Edinburgh: Pearson Education Limited. 
Shafiq, M., 2012. Implementation of quality management systems and business excellence frameworks in Pakistani textile companies. Journal of Quality and Technology Management, 7(2), pp.11-23.

Sila, I. and Ebrahimpour, M. (2002). An investigation of the total quality management survey based research published between 1989 and 2000: A literature review. International Journal of Quality \& Reliability Management, 19(7), 902-970.

Sila, I. and Ebrahimpour, M. (2005). Critical linkages among TQM factors and business results.International Journal of Operations \& Production Management, 25(11), 1123-1155.

Sitkin, S.B., Sutcliffe, K.M. and Schroeder, R.G. (1994). Distinguishing control from learning in total quality management: A contingency perspective. Academy of Management Review, 19(3), 537-564.

Sousa, R. and Voss, C.A. (2002). Quality management re-visited: a reflective review and agenda for future research. Journal of Operations Management, 20, 91-109.

Spencer, B.A. (1994). Models of organisation and Total Quality Management: A comparison and critical evaluation. The Academy of Management Review, 19(3), 446-471.

Su, Q., Li, Z., Zhang, S.X. and Liu, Y.Y. (2008). The impacts of quality management practices on business performance. International Journal of Quality \& Reliability Management, 25(8), 809-823.

Tan, Boon-In. (2013), "TQM adoption and organisational performance of family owned businesses: a literature review and proposed structural model." International Journal of Modelling in Operations Management 3.1: 1-19.

Tabachnick, B.G. and Fidell, L.S. (2007). Using multivariate statistics. 5th Edition. Boston: Pearson Education. 
Tari, J.J. and Molina-Azorin, J.F. (2010). Integration of quality management and environmental management systems: Similarities and the role of the EFQM model. The TQM Journal, 22(6), 687-701.

Tari, J.J., Molina, J.F. and Castejon, J.L. (2007). The relationship between quality management practices and their effects on quality outcomes.European Journal of Operations Research, 183, 483-501.

Vecchi, A., \& Brennan, L. (2009). Quality management: a cross-cultural perspective. Cross Cultural Management: An International Journal, 16(2), 149-164.

Vecchi, A., \& Brennan, L. (2011). Quality management: a cross-cultural perspective based on the GLOBE framework. International Journal of Operations \& Production Management, 31(5), $527-553$.

Walsh, P. (1995). Overcoming chronic TQM fatigue. The TQM Magazine, 7(5), 58-64.

Yong, J. and Wilkinson, A. (2001). Rethinking Total Quality Management. Total Quality Management, 12(2), 247-258.

Westlund, A.H. (2001). Measuring environmental impact on society in the EFQM system. Total Quality Management, 12(1), 125-135.

Wiele, A.V.D., Williams, A.R.T. and Dale, B.G. (2000). ISO 9000 series registration to business excellence: the migratory path. Business Process Management, 6(5), 417-427.

Witcher, Barry. (1994). The adoption of Total Quality Management in Scotland. The TQM Magazine, Vol. 6, No. 2, 1994, pp. 48-53.

Yoo, D.K., Rao, S.S. and Hong, P. (2006). A comparative study on cultural differences and quality practices - Korea, USA, Mexico, and Taiwan." International Journal of Quality \& Reliability Management, 23(6), 607-624. 
Zairi, M., Letza, S. R. and Oakland, J. S. (1994). Does TQM Impact on Bottom-line Results? The TQM Magazine, 6(1), 38-43. 